\title{
KENIKMATAN IRONIS BAGI MANTAN PREMAN DI YOGYAKARTA SETELAH MENONTON SINETRON PREMAN PENSIUN
}

\author{
Yul Rachmawati dan Tangguh Okta Wibowo \\ Kajian Budaya dan Media \\ Sekolah Pascasarjana Universitas Gadjah Mada \\ Emai:yulrachmawati@gmail.com
}

\begin{abstract}
This study attempts to explore how the reception of the audiences after watching Preman Pensiun (PP) soap opera, a comedy soap opera by Aris Nugraha which has aired up to three series. The problematization of this study comes when PP soap opera raises a question, how do audiences' response in the city other than Bandung? This study tries to understand how receptive thugs who are retired or ex-thugs after watched PP soap operas in their daily lives. For data collection, researchers conducted in-depth interviews after approaching three informants as former thugs in Yogyakarta. The result of this study is the communication of former thugs in daily life after they have constructed and reproduced values adopted from PP soap opera. Last, PP soap opera gives pleasure for the ex-thugs in providing entertainment, but also it gives ironic pleasure and paradox when they feel away with the pleasure.
\end{abstract}

Keywords: daily lives of ex-thugs; ironic pleasure; Preman Pensiun soap opera; reception of thugs

ABSTRAK

Studi ini mencoba untuk mengeksplorasi bagaimana resepsi audiens setelah melihat sinetron Preman Pensiun, sinetron komedi karya Aris Nugraha yang telah ditayangkan hingga tiga seri. Problematisasi hadir ketika sinetron PP memunculkan sebuah pertanyaan, bagaimana respon di kota selain Bandung? Studi ini berusaha memahami bagaimana resepsi preman yang telah pensiun atau mantan preman setelah menonton sinetron PP di kehidupan mereka sehari-hari. Untuk pengumpulan data, peneliti melakukan wawancara secara mendalam setelah melakukan pendekatan dengan tiga informan mantan preman di Yogyakarta. Hasil dari studi ini adalah komunikasi kehidupan mantan preman di kehidupan sehari-hari setelah mereka turut mengonstruksi dan mereproduksi nilai yang mereka adopsi dari sinetron tersebut. Terakhir, sinetron PP ini memberikan kenikmatan kepada mantan preman dalam memberikan hiburan, tetapi juga menjadi kenikmatan yang ironis (ironic pleasure) dan paradoks ketika mereka berjarak dengan kenikmatan tersebut.

Kata kunci: kehidupan mantan preman; kenikmatan yang ironis; sinetron Preman Pensiun; resepsi mantan preman

\section{LATAR BELAKANG}

Preman Pensiun (PP) merupakan salah satu sinetron komedi karya Aris Nugraha. Sejak sesi satu ditayangkan pada tanggal 12 Januari 2015, sinetron ini dibuat serialnya, yaitu dengan dilanjutkan sinetron PP sesi dua yang tayang sejak 25 Mei 2015 dan sesi tiga yang tayang 14 Desember 2015. Secara statistik, sinetron ini selalu mendapatkan peringkat (ratings) yang bagus. Dilansir dari tabloid Bintang bahwa sinetron Preman Pensiun 2 meraih TVR 3,9 dan TVS 22 dan episode perdana Preman Pensiun 3 juga mendapat ratings yang baik dan tertinggi di jam 
tayangnya yaitu menduduki posisi 6 dengan TVR 3,3 dan TVS 22,2 (Rayendra, 2015a).

Kepopuleran sinetron PP tidak dapat dilepaskan dari andil sang penulis skenario dan sutradara yang menampilkan pada masyarakat Indonesia dalam melihat Bandung melalui perspektif lain. Sinetron PP ini menampilkan kehidupan masyarakat marginal di kota Bandung, seperti preman, pencopet, pedagang, supir, pembantu, dan tukang parkir. Dengan kata lain, sinetron PP berusaha mengangkat kehidupan kaum marginal yang berada di kota Bandung dengan menjadikan preman sebagai tokoh utamanya.

Problem kaum marginal yang digambarkan melalui media sinetron yang ditayangkan di televisi nasional dengan harmonisasinya dan bernuansa komedi. Konsumsi masyarakat Indonesia pada sinetron yang menampilkan kehidupan preman yang biasanya distereotipkan sebagai seseorang yang "jahat" dan "kejam" ini pun tergolong cukup tinggi, yang dapat dibuktikan dengan tingginya rating sinetron PP yang menceritakan seluk beluk kehidupan preman. Istilah preman ini diidentikan dengan orang jahat yaitu seseorang yang menganggu ketertiban masyarakat dengan kejahatan yang sudah di luar batas kemanusiaan (Bio Pustaka, 2008).

Dengan segala dinamikanya, sinetron yang mengangkat kisah kehidupan seharihari preman dengan mendapatkan respon positif dari masyarakat, baik dari masyarakat yang tinggal di Bandung, maupun masyarakat di luar kota Bandung. Dilansir dari tabloid Bintang bahwa karena rating yang tinggi, RCTI telah menayangkan ulang sebanyak dua kali sinetron PP (Rayendra, 2015b).

Meskipun demikian, kehadiran sine- tron PP memunculkan sebuah pertanyaan, lalu bagaimana respon penonton di kota selain Bandung? Problematisasi atas tontonan ini juga pasti beragam dari semua kalangan masyarakat, terutamanya mantan preman itu sendiri. Berdasarkan konteks bagaimana resepsi mantan preman yang menonton sinetron PP dalam berkomunikasi dengan pihak luar di kehidupan sehari-hari menjadi menarik dikaji. Terlebih, penelitian ini dilakukan dari bawah, artinya penelitian ini memahami melalui sudut pandang down to top, yaitu melihat persoalan dari kehidupan sehari-hari mantan preman, bukan dari tingginya rating dan respon yang bagus secara umum. Hal ini karena sifat masyarakat yang majemuk dan tidak dapat digeneralisasi.

Oleh karena itu, studi ini berupaya melakukan eksplorasi kehidupan mantan preman secara spesifik di Yogyakarta. Penelitian ini tentu saja tidak bertujuan untuk menggeneralisir atau menghasilkan kesimpulan yang umum, tetapi penelitian ini ingin membawa kehidupan sehari-hari masyarakat, terutamanya mantan preman di Yogyakarta, sebagai praktik pemaknaan yang bermakna bagi mereka setelah menonton sinetron PP dan bagaimana mereka berkomunikasi dengan pihak luar dari dirinya, seperti keluarga dan lingkungan sekitar. Preman yang akan difokuskan dalam penelitian ini adalah preman yang sudah tidak lagi menjalankan aktivitas mereka sebagai preman dan telah beralih profesi kepada pekerjaan yang lain (pensiun), sedangkan sebutan bagi preman yang telah pensiun tersebut, kami menggunakan istilah mantan preman. 


\section{KAJIAN LITERATUR}

Khalayak bukan lagi hanya merepresentasikan "objek penelitian," tetapi diartikan juga sebagai discursive trope yang menandakan bahwa berbagai hal selalu berubah, yaitu makna selalu dikonstruksi dan dikontestasikan dalam konteks penggunaan dan konsumsi media dalam keseharian (Ang, 1996: 4). Khalayak diartikan sebagai produsen makna teks dan teknologi yang aktif dengan produksi makna yang bergantung pada kehidupan mikropolitik sehari-hari khalayak (Ang, 1996: 8). Menurut, Michel de Certeau (1984) bahwa untuk memahami konsumen (dalam konsteks ini sebagai audiens) yang seringkali dianggap pasif, kita dapat mengeksplorasi dan menginvestigasinya melalui kehidupan sehari-hari mereka.

Hall (1981; Barker, 2000: 287) mengartikan proses pengkodean (encoding) televisi sebagai "suatu artikulasi momenmomen produksi, sirkulasi, distribusi, dan reproduksi yang saling terhubung tetapi dengan praktik yang berbeda-beda yang tidak menjamin momen berikutnya." Jadi pengkodean secara umum adalah proses ketika tanda diorganisasikan menjadi kode, sedangkan penafsiran kode (decoding) merujuk pada proses resepsi ketika audiens menafsirkan kode dan menghasilkan makna atasnya (Barker, 2004:58).

Makna adalah sesuatu yang tidak tunggal atau bersifat beragam, tetapi sangat bergantung pada posisi dari penonton sehingga makna sepenuhnya dapat bertransformasi. Penonton dalam hal ini memiliki 'kuasa' untuk mengolah makna, sehingga dari konsep inilah Hall menyebut bahwa konsumen adalah produser juga (Hall, 1993:512).
Lebih jauh, respon audiens ini akan terlihat dari kehidupan sehari-hari mereka, termasuk dengan peranan sinetron PP terhadap identitas yang secara tidak langsung terbentuk dalam kehidupan mantan preman. Anthony Giddens (1991: 54) menyebutkan bahwa identitas diri merupakan sebuah proyeksi refleksif yaitu suatu upaya yang dilakukan dan dipikirkan terus menerus. Di mana kita menciptakan, mempertahankan dan merevisi sekumpulan narasi bibliografis (cerita tentang siapa kita dan bagaimana kita ada di tempat kita saat ini). Maka Giddens (1991) dalam bukunya yang berjudul Modernity and Self-Identity mengatakan bahwa pertanyaan-pertanyaan yang seringkali berada dalam masyarakat modern akhir adalah apa yang harus dilakukan (what to do), bagaimana cara bertindak (how to act), dan menjadi siapa (who to be) Giddens juga menyebutkan bahwa identitas diri sebagai proyeksi artinya apa yang kita pikir tentang diri kita berubah dari situasi ke situasi lain menurut ruang dan waktunya (Barker, 2000:175). Selanjutnya, bagi Giddens, identitas adalah apa yang dipikirkan oleh individu tersebut, tetapi apa yang dipikirkan dapat berubah sesuai ruang dan waktunya. Menurut Gauntlett (2008:107) bahwa identitas yang terus mengalami perubahan ini menyebabkan kita dapat membuat, menjaga dan merevisi sekumpulan narasi biografis kita, yaitu tentang siapa kita dan bagaimana kita dapat berada di tempat kita yang sekarang.

Secara krusial, teks media and interdiskursif konteks adalah sebuah elemen yang berhubungan satu dengan lain (Scollon 2001; Briggs 2006:456). Tanpa keraguan (seperti yang telah diuraikan Lindlof and Traudt (1983; Moores 1990; Morley 1989; Silverstone 1994; Briggs 2006: 457) bahwa 
satu hal terpenting dalam analisis audiens, yaitu menggali kompleksitas hubungan antara teks, konteks, dan audiens dan cara yang diatur oleh peraturan media pada kehidupan sosial. Oleh karena itu, tulisan ini mencoba menghubungkan antara resepsi audiens dengan sinetron PP dan dalam konsteks kehidupan mantan preman.

\section{METODE PENELITIAN}

Untuk pengumpulan data, penelitian ini dilakukan dengan wawancara secara mendalam dengan informan, yaitu beberapa mantan preman di Yogyakarta. Teknik pengumpulan data primer dilakukan dengan mencari informan yang tersebar di Yogyakarta. Kemudian dilakukan pendekatan dengan tiga orang informan, yaitu wawancara mendalam masing-masing (nama informan disamarkan), Anto (pria, umur 60 tahun) sekitar tujuh bulan dari bulan Desember 2015-Juni 2016, Aris (pria, umur 42 tahun) sekitar empat bulan dari bulan Februari-Mei 2016, dan Heru (pria, umur 38 tahun) sekitar dua bulan dari bulan AprilJuni 2016.

\section{PEMBAHASAN}

Sinetron Preman Pensiun (PP) merupakan sinetron komedi yang menceritakan kehidupan premanisme di kota Bandung. Sebagai sinetron komedi pertama di Indonesia yang menyajikan cerita tentang premanisme sebagai tema cerita. Secara tidak langsung, melalui sinetron PP ini terdapat kisah hidup yang ingin direvisi untuk kemudian diproduksi kembali sebagai sebuah kisah hidup yang baru. Tidak hanya informan yang mengonstruksi apa yang terdapat dalam tayangan sinetron PP, tetapi juga sinetron PP berusaha menampilkan wacana premanisme dengan sudut pandang yang berbeda karena preman dikisahkan lebih humanis, lucu, menyenangkan, dan suka bercanda.

Sinetron PP yang menceritakan preman sebagai tokoh sentral beserta likaliku kehidupannya mempunyai kemiripan jalan cerita dengan kisah kehidupan ketiga informan. Kemiripan cerita sinetron PP ini secara tidak langsung membuat ketiga informan memiliki kedekatan emosional, karena sinetron ini turut mengingatkan mereka terhadap kehidupan informan pada masa lalu dan sekarang. Sinetron PP membawa informan kembali kepada masa lalu mereka sebagai preman. Memori atas apa yang pernah mereka lalukan di masa lalu kembali hadir ketika menonton, karena seakan ada kedekatan personal antara sinetron PP dengan mereka.

Berdasarkan hasil wawancara, sinetron ini mampu membawa perubahan positif bagi para preman yang hendak menanggalkan profesinya. Setidaknya, sinetron ini turut memotivasi para preman bahwa mereka bisa memperjuangkan cita-cita yang selama ini tertanam dalam dirinya. Kisah Gobang dalam sinetron PP yang dari dulu memiliki cita-cita untuk beternak lele akhirnya tercapai melalui kerja keras. Berkali-kali ia mengalami kegagalan untuk berwirausaha, belum lagi istrinya yang selalu mengeluh ketika Gobang tidak dapat memenuhi keinginannya untuk membeli rumah baru atau perhiasan, tetapi pada akhirnya ia memperoleh apa yang diusahakannya. Seperti pada petikan wawancara dengan salah satu informan (Aris): "Ya, (sinetron ini) memberikan contoh yang baik untuk preman-preman tadi biar pada insaf, jualan cilok atau kue balok. Kalau ada yang (sinetron PP) ke-4, 
saya akan senang. " Dengan adanya sinetron ini, Aris berharap bahwa melalui sinetron PP ini dapat memberikan motivasi kepada para preman untuk segera insaf dan beralih kepada profesi lain.

Meskipun informan merespon positif terhadap sinetron ini, tetapi di sisi lain sinetron ini juga menjadi pemantik untuk mengingat sebuah peristiwa politik yang terjadi pada pemerintahan Soeharto, yaitu Operasi Pemberantasan Kejahatan (OPK) atau Penembakan Misterius. Bagi informan, sinetron ini tidak hanya mengingatkan pada kronologi peristiwanya saja, tetapi juga siapa saja yang terlibat dalam peristiwa tersebut. Menurut Hansen (2011: 33) bahwa masingmasing informan menuturkan apa yang mereka ingat berdasarkan memori personal atau autobiografi yang merupakan sebuah proses ketika informan menceritakan kisah hidup yang dirasakan dan dilakukannya pada dirinya dan orang lain.

Terutamanya Anto, sinetron ini memberikan efek traumatis kepadanya dibandingkan dibandingkan kedua informan yang lain, karena Anto mengalami peristiwa tersebut secara langsung. Hal ini berbeda dengan Aris dan Heru yang kala itu masih anak-anak. Bagi Aris dan Heru, peristiwa tersebut tidak terlalu memberikan efek traumatis yang mendalam. Seperti yang diutarakan De Certeau (1984:108) bahwa jika kenangan tersebut sifatnya personal hanya diketahui oleh individu. Sifat dari kenangan ini bisa jadi tidak menarik bagi orang lain, tetapi bermakna bagi diri mereka sendiri.

Ketika kami menanyakan tentang peristiwa tersebut, Anto membutuhkan waktu untuk mengingat sebuah peristiwa yang telah banyak menghabisi nyawa rekan-rekannya.
Dengan berat hati, ia pun menyebutkan nama-nama temannya sesama preman. Ada rasa syukur sekaligus kehilangan yang mendalam dalam diri Anto atas peristiwa tersebut. Rasa bersyukur karena ia selamat dari OPK, tetapi ia merasakan duka yang mendalam, karena anak buah dan sahabatnya banyak yang menjadi korban peluru, seperti pada verba tim berikut:

"[teman-teman saya] sudah tidak ada, kebanyakan tertangkap OPK. Seperti galigali itu, kebanyakan rata-rata yang sama seperti saya, mereka mati tertangkap OPK. OPK seperi operasi tentara, di tembak saja. Kebanyakan matinya ditembak di jalan-jalan." (Anto)

Menurut Pranoto, istilah gali merupakan sebuah merupakan komunitas yang tidak mempunyai aturan dan sopan santun yang standar, belum jinak, dan tidak mendapat pelajaran budaya halus (Pranoto, 2008: 41). Peristiwa tersebut melekat kuat dalam ingatan Anto dan dapat kembali hadir ketika ada pemantiknya. Sinetron PP sebagai media audiovisual yang ditayangkan melalui televisi membawa Anto pada kenangan masa lalu di zaman Orde Baru.

Di sisi lain, Aris tidak hanya dapat membayangkan rusuhnya OPK, tetapi juga membawanya pada berbagai peristiwa bersejarah lainnya yang memakan banyak korban, seperti tragedi Trisakti yaitu penembakan yang terjadi pada 12 Mei 1988 terhadap empat mahasiswa trisakti yang menuntut Soeharto untuk turun, dan pembunuhan wartawan Yogyakarta bernama Udin yang tidak banyak diberitakan oleh media pada saat itu. Hal tersebut tentunya sangat disayangkan oleh kedua informan, yaitu Aris dan Heru. "Ya, gimana ya Mbak, dia yang dibunuh itu preman, kalau tidak 
[preman] ya mungkin ada media ....misalnya Udin dekat sini wartawan Yogyakarta yang dibunuh" (Heru). Heru yang mengaku rumahnya berdekatan dengan wartawan bernama Udin sangat menyayangkan atas minimnya media yang meliput peristiwa tersebut. Heru menduga bahwa minimnya pemberitaan Udin dikarenakan pembunuhan tersebut melibatkan preman yang selalu dianggap sebagai pemicu kriminalitas yang harus dimusnahkan di Indonesia.

Dalam hal ini, proses pengingatan (remembering) dan pelupaan (forgetting) menjadi hal yang sangat penting ketika menyampaikan sebuah gagasan terkait satu peristiwa bersejarah, seperti dua sisi mata uang. Menurut Budiawan (2013:150), politik ingatan bukanlah tentang apa yang terjadi sesungguhnya di masa lalu, tetapi bagaimana masa lalu itu diingat, sehingga politik memori tidak akan memperdebatkan terkait fakta masa lalu, melainkan bagaimana orang menuturkan dan sekaligus memaknai masa lalu. Melalui penuturan informan terkait masa lalu tersebut, dapat dilihat bagaimana pemaknaan masa lalu membentuk dan sekaligus dibentuk oleh informan untuk menunjukkan rasa kediriannya (sense of self).

Lebih jauh, sinetron PP telah membawa Anto, Aris dan Heru memaknai masa lalu dengan segudang pertanyaan terkait preman yang selalu dipandang sebagai 'musuh negara'. Keberadaannya tidak diharapkan, bahkan jasadnya menjadi objek incaran peluru aparat. Minimnya pemberitaan peristiwa politik masa Orde Baru seperti OPK, Trisakti, dan pembunuhan wartawan Udin membuat mereka berpikir betapa preman diklasifikasikan sebagai sosok yang marginal hingga tidak layak untuk diperjuangkan keberadaannya.
Selanjutnya, kami akan membahas bagaimana informan memproyeksikan identitas mereka melalui hadirnya sinetron PP di televisi, sekaligus memposisikan diri mereka dalam proses negosiasi, yaitu pada bagaimana mereka berusaha menciptakan, mempertahankan, dan memperkenalkan ulang tentang siapa dirinya. Keputusan ketiga informan untuk berhenti dari dunia premanisme yang telah membesarkan nama mereka bukanlah sebuah proses yang ringkas dan sederhana, tetapi membutuhkan pemikiran yang matang di tengah perjalanan kehidupannya yang kompleks. Banyak peristiwa yang harus dilewati dan tidak sedikit orang yang harus mereka temui terlebih dahulu sebelum akhirnya memutuskan berhenti dari dunia premanisme.

Label mantan preman membuat diri mereka terkesan ambigu ditengah makna preman yang terus mengalami perubahan. Para mantan preman nampaknya harus menyesuaikan diri dalam interaksi untuk menunjukkan bahwa mereka telah berhenti menjadi preman. Dengan hati-hati, ada peran yang sengaja mereka tampilkan untuk menunjukkan identitasnya dan ada pula peran yang disembunyikan.

Proyeksi identitas mantan preman diwarnai keinginan bahwa mereka ingin hidup 'normal' seperti orang lain. Pertama kali bertemu dengan Anto, secara gamblang ia menunjukkan bahwa ia pernah menjadi 'orang yang rusak'. Senada dengan Anto, alasan terbesar Aris berhenti dari dunia terminal adalah karena ia ingin hidup "normal" atau "lumrah" seperti orang lain, sedangkan Heru menganggap bahwa preman sebenarnya adalah korban dari kesulitan hidup yang semakin sulit.

Bagi Heru, ia belum meninggalkan 
kebiasannya semasa menjadi debt collector, yaitu minum minuman keras. Ia mengakui bahwa hal tersebut dilakukan ketika sedang ingin saja di dalam rumah, karena istrinya yang melarang untuk minum di luar rumah. Pemikiran untuk kembali dan berhenti menjadi debt collector (DC) masih selalu membayangi Heru. Ketegangan itu kembali hadir jika ada faktor eksternal yang kembali mengingatkan Heru akan masa lalunya. Misalnya ketika ia menonton sinetron PP yang menggambarkan DC, ia teringat masa lalunya sebagai DC yang seketika hadir dalam benaknya pada saat pemeran DC dalam sinetron PP yang mirip dengan kesehariannya dahulu. Proyeksi identitas para mantan preman tidak hanya dipengaruhi oleh faktor internal yang berusaha dinarasikan oleh mereka. Akan tetapi terdapat faktor eksternal yang juga turut membentuk proyeksi identitas mereka, misalnya adalah adanya adanya pihak diluar diri yang turut mempengaruhi. Seperti kisah Kang Bahar dalam sinetron PP yang memutuskan pensiun setelah istrinya sakit keras, informan pun memutuskan berhenti karena adanya pengaruh keluarga.

Bagi informan, mereka memiliki pandangan bahwa keluarga merupakan aspek terpenting dalam hidup mereka. Istri, anak, dan keluarga secara umum menjadi pihak luar yang menjadi perantara informan dengan nilai hidup menjadi baik dan buruk dan kemudian menjadi tolak ukur dalam berbuat segala sesuatu dalam hidup.

Kemiripan cerita yang terdapat dalam sinetron PP yang mengisahkan Kang Bahar memutuskan pensiun sebagai preman karena faktor istrinya yang sakit membuat informan merefleksikan narasi diri mereka yang begitu mirip. Tidak hanya kisah Kang
Bahar yang membuat mereka teringat pada masa lalunya, tetapi juga Kisah Kang Mus yang memutuskan pensiun karena selalu mengingat kata-kata Kang Bahar bahwa "bisnis premanisme adalah bisnis bagus, tetapi bukan bisnis baik". Pesan dari Kang Bahar selalu mengingatkan Kang Mus bahwa suatu hari nanti ia pun akan melakukan hal yang serupa dengan Kang Bahar, yaitu pensiun dari dunia premanisme. Seperti Kang Bahar, Kang Mus selaku pimpinan tertinggi premanisme selalu mengingatkan pada anak buahnya dengan pesan "kita adalah keluarga". Faktor kebersamaan dan persaudaraan yang begitu melekat menjadi alasan yang kuat bagi para preman untuk berhenti dari dunia yang selama ini dianggap "abnormal" dan beralih pada kehidupan "normal". Konteks normal dan abnormal semakin menjelaskan bahwa identitas bukanlah hanya soal deskripsi diri melainkan juga label sosial yang dapat diidentifikasi dari hak dan kewajiban yang membentuk peran diri (Giddens dalam Barker, 2000 : 176).

Kedekatan pengalaman masa lalu yang hampir serupa antara yang ditayangkan dalam sinetron dengan pengalaman informan membuat mereka dapat merasakan kenikmatan ketika menonton. Akan tetapi, hal ini juga menjadi paradoks tersendiri karena kenikmatan tersebut menjadi luntur ketika informan menganggap bahwa alur cerita terkesan monoton, tidak ada klimaks, dan latar belakang tempat yang tidak pernah berubah. Kesamaan pengalaman hidup informan dengan apa yang diceritakan dalam sinetron membawa implikasi pada kemampuan informan membandingkan hingga berujung pada kejenuhan terhadap jalan cerita.

Di sisi lain, kisah sinetron PP yang menampilkan berbagai jenis preman dengan 
tingkatan kekuasaanya membuat informan kembali merefleksikan pengalaman serupa yang menurut mereka memiliki kemiripan dengan kehidupan yang berada pada sinetron. Kisah Kang Bahar yang dapat dikatakan sebagai bos preman yang kemudian digantikan oleh Kang Mus dengan anak buahnya yang tersebar di jalanan, terminal, dan pasar membuat informan kembali teringat akan masa lalunya yang dahulu pernah hidup di tiga tempat tersebut.

Berdasarkan sinetron PP, informan menilai posisi kepremanannya: ada yang "lebih preman" dan "kurang preman." Sebagai preman senior, Anto mampu mengoreksi kehidupan di pasar dan jalanan yang diceritakan dalam sinetron, terutama yang tidak sesuai dengan pengalamannya. Misalnya dalam episode terakhir adegan Kang Mus yang melaporkan Jamal ke polisi. Kang Mus yang dekat dengan polisi bagi Anto tak ubahnya seperti spionase atau sengaja untuk berlindung pada polisi. "Kalau kita mau merombak, jangan menggantungkan pihak yang lain. Ya sendiri saja, ya seperti saya. Ya, tonjolkan diri. Saya gak suka (jadi spionase). Jadinya, sudah dijual beli jiwanya, beda dengan realitanya." (Anto). Dari cuplikan adegan tersebut, Anto merasa apa yang ditampilkan kurang sesuai jika Kang Mus disebut preman "sejati”. Sebagai bos preman, Kang Mus seharusnya tidak menjadi matamata polisi dan melaporkan musuhnya ke pihak kepolisian. Menurut Anto, seharusnya ia menangani musuhnya, yaitu Jamal tanpa melibatkan pihak kepolisian.

Sinetron PP mereproduksi wacana premanisme dengan sudut pandang yang berbeda, misalnya preman dikisahkan lebih humanis, lucu, menyenangkan, suka bercanda, berteman dengan siapa saja termasuk polisi. Hal ini akhirnya turut mengonstruksi definisi preman kota Bandung yang dipahami oleh Anto. Anto melihat bahwa preman di kota Bandung dan Yogyakarta cukup berbeda, terutama dari segi senioritas dan kekuatannya. Preman Bandung dianggap sebagai preman yang masih baru dan tidak terlalu kuat, berbeda halnya dengan Jakarta dan Yogyakarta. Selain membandingkan dengan kota Bandung, Anto juga membandingkan dengan para preman yang berada di luar Jawa. Anto beranggapan bahwa preman Yogyakarta pada dasarnya adalah orang baik, karena rata-rata sangat perasa. "Kalau Yogyakarta segali-galinya.. perasaannya tidak bisa, karana dipacu dengan lingkungan saja. Jadi kerasnya luar biasa." Keterpaksaan bersikap keras adalah faktor utama yang menyebabkan para gali Jogja dikategorikan sebagai gali yang kuat.

Dengandemikian, sinetron PP membuat mereka berpikir kembali tentang siapa dirinya dan merefleksikan kehidupannya dengan apa yang ditampilkan dalam sinetron. Ketiga informan akan mengadopsi beberapa adegan dan merefleksikan dengan karakter yang menurut mereka lebih mendekati dengan kehidupan sehari-hari. Termasuk secara tidak sadar, mereka membuat klasifikasi "preman kelas atas" dan "preman kelas bawah" dengan berkaca pada apa yang ditampilkan dalam sinetron dan yang pernah mereka alami. Proyeksi identitas mereka juga akhirnya dibentuk oleh media yang merupakan mediasi atau mediatisasi dari kehidupan sehari-hari yang membentuk siapa kita dan apa yang kita pikirkan tentang diri kita pada waktu tertentu (Livingstone; Lundby dalam Hansen, 2011: 33). 


\section{KESIMPULAN}

Di bagian ini, aktivitas menonton sinetron PP membuat informan mereproduksi nilai yang telah mereka konsumsi dari sinetron PP tersebut di kehidupan sehari-hari mereka yang terkadang sulit ditemui ketika melakukan penelitian dengan sudut pandang aerial. Menurut Saukko, individu dapat bertindak dan mengutarakan lebih banyak atas apa yang dipikirkan ketika dilihat dari bawah ke atas dari pada dilihat secara aerial (atas ke bawah) (Saukko, 2003:165). Selanjutnya, penelitian membawa kesimpulan bahwa sinetron ini membawa informan kepada pada sebuah kenikmatan (pleasure), yang pada akhirnya menjadi kenikmatan yang ironis (ironic pleasure) dan paradoks ketika mereka berjarak dengan kenikmatan tersebut. Sinetron ini membawa informan untuk merasakan kecemasan akan stigma masyarakat sekitarnya yang dapat muncul kembali, sekaligus proyeksi identitas mereka yang mengingatkan pada rasa kebanggaan terhadap kekuasaan yang pernah mereka punya sebagai preman di masa lalu.

\section{REFERENSI}

Ang, I. (1996). Living Room Wars : Rethinking media audiences for a postmodern world. New York: Routledge.

Barker, C. (2000). Cultural Studies : Teori dan Praktik. Yogyakarta: Kreasi Wacana.

Barker, C. (2004). The Sage Dictionary of Cultural Studies Dictionary . London: Sage.

Bio Pustaka. (2008). Apakah Soeharto Pahlawan. Yogyakarta: Bio Pustaka.

Briggs, Matt. 2006. "Beyond the audience:
Teletubbies, Play and Parenthood." European Journal of Cultural Studies. Volume: 9, Halaman 441-460, Online: SAGE Publications. (http://ecs. sagepub.com/content/9/4/441).

Budiawan (Ed.). (2013). Sejarah dan Memori : Titik Simpang dan Titik Temu. Yoyakarta: Ombak.

de Certeau, M. (1984) The Practice of Everyday Life. Diterjemahkan oleh Steven Rendall. California: University of California Press.

Gauntlett, D. (2008). Media, Gender and Identity : An Introduction. New York: Routledge.

Giddens, A. (1991). Modernity and Self-Identity : Self and Society in the Late Modern Age. USA: Stanford California Press.

Hall, S. (1993). Encoding-Decoding in The Cultural Studies Reader. (S. During, Ed.) London: Routledge.

Hansen, J. G. (2011). Media and Memory. Edinburgh: Edinburgh University Press.

Pranoto, S. W. (2010). Jawa (Bandit-bandit Pedesaan): Studi Historis 1850-1942. Yogyakarta: Graha Ilmu.

Rachmawati, Y. 2017. "Kenikmatan dan Proyeksi Identitas: Aktivitas Menonton Mantan Preman Yogyakarta Terhadap Sinetron Preman Pensiun." Tesis. Yohyakarta: Sekolah Pascasarjana UGM.

Rayendra, P. 2015a. "Rating Epsiode Perdana Preman Pensiun 3 Tak Setinggi Preman Pensiun 2." Tabloid Bintang. 21 Desember 2015. Web 15 Desember 2015. (http://www.tabloidbintang.com/ articles/film-tv-musik/ulasan/30368rating-episode-perdana-premanpensiun-3-tak-setinggi-premanpensiun-2) 
Rayendra, P. 2015b. "Spektakuler, Rating Episode Perdana Preman Pensiun 2". Tabloid Bintang. 14 Oktober 2015. Web 26 Mei 2015. (http://www.tabloidbintang.com/ articles/film-tv-musik/ulasan/22409spektakuler rating-episode-perdana preman-pensiun-2).
Saukko, Paula. (2003). Doing Research in Cultural Studies: An Introduction to Classical and New Methodological Approaches. London: Sage Publications. 